\title{
Profile Secondary Metabolite Compounds and Antioxidant Activities of Stem Bark Jambu Mete (Anacardium occidantale L.) Extract
}

\author{
*Tarso Rudiana ${ }^{\text {a) }}$, Dhyneu D. Jayanti ${ }^{\text {b) }} \&$ Siti Solehah ${ }^{\text {b) }}$ \\ a) Kimia/FSFK - Universitas Mathla'ul Anwar, Pandeglang - Indonesia 42273 \\ b) Farmasi/FSFK - Universitas Mathla'ul Anwar, Pandeglang - Indonesia 42273 \\ Received 09 May 2021, Revised 14 June 2021, Accepted 05 August 2021 \\ doi: $10.22487 /$ j24775185.2021.v10.i3.133-138
}

\begin{abstract}
Oxidative stress is a condition in which the amount of free radicals and antioxidants in the body is not balanced, causing various diseases. One of them is a degenerative disease. Antioxidant compounds can reduce oxidative stress. Anacardium occidentale $L$. is a type of plant from the Anacardiaceae family. This plant is found in many trophic countries, including Indonesia, and is believed to ward off degenerative diseases caused by oxidative stress. The purpose of this study was to analyze the activity of $A$. occidentale stem bark extract against DPPH radical inhibition (1,1-Diphenyl-2Picrilhidrazil) and the profiling of secondary metabolites in their active fraction. The bark of $A$. occidentale was extracted by a gradient maceration method. The solvents used were n-hexane (nonpolar), ethyl acetate (semi-polar), and methanol (polar). The macerate was concentrated using a rotary vacuum evaporator. The macerate concentrated was tested for DPPH radical inhibition using a spectrophotometer. The most active extract was analyzed for chemical content by LC$M S / M S$. The results showed that the A. occidentale stem bark section had antioxidant activity. Methanol extract obtained very strong and best antioxidant activity with an IC50 value of $47.13 \mathrm{ppm}$ compared to ethyl acetate extract and $n$-hexane extract, with IC50 values of $163.92 \mathrm{ppm}$ and $501.72 \mathrm{ppm}$, respectively. Secondary metabolites that are thought to have antioxidant activity in the methanol extract of $A$. occidentale stem bark are epigallocatechin (EC) and epigallocatechin gallate (EGCG) compounds.
\end{abstract}

Keywords: Antioxidant, extraction, flavonoids, free radicals, stress oxidative

\section{Introduction}

Various types of plants with potential as medicinal plants grow in many trophic countries such as Indonesia. Cashew (Anacardium occidentale), which Indonesian people trusted, can ward off oxidative stress. Oxidative stress is a condition that describes an imbalance of free radicals and antioxidants in the body and is one of the causes of degenerative diseases (Arief \& Widodo, 2016). Based on WHO data, in 2019, degenerative diseases such as diabetes, cardiovascular disease, respiratory disorders, and cancer are still the highest mortality in both developing and developed countries, with a mortality rate of $15 \%$ in Southeast Asia, including Indonesia.

Dahlia \& Hasnawati (2014) explained that free radicals are reactive in the body and inhibited by antioxidant compounds. High concentrations of free radicals can cause cell structure to become damaged, causing oxidative stress (Arnanda \& Nuwarda, 2019). According to Sinaga (2016), the process of respiration from the body contributes to several free radicals. The inhaled oxygen produces energy in ATP and has reactive oxygen species (ROS). If it is not controlled, it can cause damage. Free radicals can also be generated from outside the body, such as air pollutants, alcohol, cigarettes, and ultraviolet radiation (Khaira, 2010).

Research on $A$. occidentale plants has been widely carried out, including the leaves reported that the Inhibition Concentration value of $50 \%$ or $\mathrm{IC}_{50}$ against antioxidant activity shows high antioxidant activity (Kusumowati, 2011). In the stem bark of $A$. Occidentale, in a study conducted by Carolus et al. (2014), there are flavonoid compounds. Tangkuman et al. (2017) reported that on the stem bark of $A$. occidentale, phenolic compounds such as gallic acid are thought to have antibacterial activity in thrush sufferers with the largest inhibition zone of $15.5 \mathrm{~mm}$. Anwar (2017) reported that $A$. occidentale fruit extract with ethanol and $\mathrm{n}$-hexane solvents had $\mathrm{IC}_{50}$ values of 3.61 and $12.52 \mu \mathrm{g} / \mathrm{mL}$. Yati et al. (2017) explained that antioxidant activity is related to bioactive

\footnotetext{
*Correspondence:

Tarso Rudiana

e-mail: tarso.rudiana@gmail.com

(c) 2021 the Author(s) retain the copyright of this article. This article is published under the terms of the Creative Commons Attribution-NonCommercial-ShareAlike 4.0 International, which permits unrestricted non-commercial use, distribution, and reproduction in any medium, provided the original work is properly cited.
} 
compounds such as flavonoids, tannins, alkaloids, terpenoids and steroids, and saponin compounds that can act as antioxidants.

The lack of information regarding the benefits of $A$. occidentale stem bark as an antioxidant requires scientific research. So in this study, the stem bark extraction of $A$. occidentale was carried out with nhexane, ethyl acetate, and methanol as solvent. Each extract was tested for antioxidant activity using the DPPH method. The most active extract was characterized using LC-MS/MS.

\section{Methods}

\section{Materials}

The stem bark of $A$. occidentale, n-hexane $\left(\mathrm{C}_{6} \mathrm{H}_{14}\right)$ (Technical grade), ethyl acetate $\left(\mathrm{C}_{4} \mathrm{H}_{8} \mathrm{O}_{2}\right)$ (Technical grade), methanol $\left(\mathrm{CH}_{3} \mathrm{OH}\right)$ (Merck), DPPH (Sigma-Aldrich), vitamin C (Sigma-Aldrich), distilled water, acetonitrile LC-MS grade (Merck).

\section{Sample preparation}

The stem bark of A. occidentale was obtained from Tarogong Village, Labuan Banten. Simplicia is made from fresh A. occidentale stems, taken from the main stem bark and branches as $6 \mathrm{~kg}$. The stem bark of A. occidentale is then sorted and cleaned using running water, then the stem bark of A. occidentale is cut into small pieces and dried in the sun covered with a black cloth to obtain dry simplicia. The dry simplicia is mashed until $840 \mathrm{~g}$ of dry powder is obtained.

\section{Extraction of A. Occidentale}

Extraction was carried out using a gradient or stratified maceration method (n-hexane, ethyl acetate, and methanol solvents were used). A total of $840 \mathrm{~g}$ of $A$. occidentale stem bark Simplicia powder was put into the macerator, after which it was soaked using the first solvent (n-hexane) until the solvent limit was approximately $2 \mathrm{~cm}$ above the simplicia. The macerate is filtered and separated from the residue. The residue is extracted again with a second solvent (ethyl acetate) in the same manner. The residue from the ethyl acetate bath was soaked again with methanol. The macerate n-hexane, ethyl acetate, and methanol were concentrated using a rotary vacuum evaporator to separate the solvents used.

\section{Antioxidant activity test}

The procedure for testing the antioxidant stem bark of $A$. occidentale follows the process from Molyneux (2004) and is modified:

\section{DPPH optimum wavelength measurement}

The $0.002 \%$ DPPH solution was prepared and stored at room temperature, and protected from sunlight. A total of $5 \mathrm{~mL}$ of $0.002 \% \mathrm{DPPH}$ solution was put into the cuvette using a pipette. The solution was measured at a 400-800 nm wavelength using a UV-Vis spectrophotometer.

\section{Measurement of antioxidant activity}

Samples were made of solutions at concentrations of $1000,800,600,400,200$, and 100 ppm from extracts of n-hexane, ethyl acetate, and methanol from the stem bark of $A$. occidentale. Each solution was piped into a $2 \mathrm{~mL}$ cuvette, and 2 $\mathrm{mL}$ of $0.002 \% \mathrm{DPPH}$ solution was added. Incubate in a dark room for approximately 30 minutes at room temperature, measure the absorbance at the optimum wavelength. The positive control used vitamin $\mathrm{C}$, and the blank/negative control used methanol. The data were analyzed with the $\mathrm{IC}_{50}$ value; the $\mathrm{IC}_{50}$ value indicated the concentration required for DPPH free radical scavenging as much as $50 \%$. The $\mathrm{IC}_{50}$ value is obtained by calculating the percent of inhibitory activity with the formula (1):

$\%$ inhibition $=\frac{\text { abs blanko-abs sample }}{\text { abs blanko }} \times 100 \%$

Based on equation (1), a linear regression curve is made, with the axis ( $\mathrm{x}$ ) as concentration and the axis (y) representing the percent inhibition.

Profiling the active component of stem bark of $A$. Occidentale extract using LC-MS/MS

Profiling of secondary metabolite components in ethyl acetate extract $A$. occidentale followed the procedure of Rudiana et al. (2019), which has been modified. The most active extract was dissolved in methanol and then analyzed using LC-MS/MS. A microsyringe injected the sample solution as much as $5 \mu \mathrm{L}$ into the stationary phase (column C18). The Quadrupole Time-of-Flight (QTOF) mass spectrometer was linked to an LC and used a positive ionization source (positive ESI). The capillary temperature of the Quadrupole Time-ofFlight (QTOF) system is set to $120^{\circ} \mathrm{C}$. The mobile phase flow rate (acetonitrile: methanol) is adjusted to $0.3 \mathrm{~mL} / \mathrm{minute}$. Chromatograms were analyzed using MassLynx software to obtain molecular formulas, retention times, measured mass, and calculated mass. Data interpretation is carried out using the mass bank website for the name and chemical structure of the sample. I was writing chemical structures using Chemdraw Ultra software version 12.0 .

\section{Results and Discussion}

\section{Preparation and extraction}

The extraction was performed using graded maceration/gradian with three different solvents ( $n$ hexane is non-polar, ethyl acetate is semi-polar, and methanol is polar). The maceration method was chosen so that compounds that could not withstand heating were not damaged (Soleha, 2018). According to Sogandi et al. (2019), the maceration method makes it possible to dissolve chemical compounds with the same degree of polarity. Nhexane, ethyl acetate, and methanol are evaporated using a rotary evaporator (RE 2010) at a temperature of $40-45^{\circ} \mathrm{C}$ at a speed of $120 \mathrm{rpm}$ below the boiling point of the solvent so that the 
substances contained in the sample are not damaged by high temperatures (Damayanti \& Fitriana, 2012). Table 1 shows the rendement of A. occidentale stem bark extract.

Table 1 . The yield of $A$. occidentale extract

\begin{tabular}{cc}
\hline Extract & Yield (\%) \\
\hline$n$-hexane & 0.71 \\
Ethyl Acetate & 5.48 \\
Methanol & 23.96 \\
\hline
\end{tabular}

Hasnaeni et al. (2019) explained that the yield value shows that the solvent attracts many compounds. Methanol solvent has the highest yield compared to both n-hexane and ethyl acetate solvents. Methanol is a solvent that has a hydroxyl group $(-\mathrm{OH})$ which is polar, and a methyl group ($\mathrm{CH}_{3}$ ), which is non-polar so that it can extract more bioactive components than other solvents (Romadanu et al., 2014). In addition, in the stem bark of $A$. Occidentale, there are many polar compounds such as polyphenols (flavonoids, tannins, alkaloids, and so on). Ethyl acetate has a methoxy group; this group can form a hydrogen bond with the compounds in the sample. The hydrogen bonds formed in the ethyl acetate solvent are no more potent than the methanol solvent, which has hydroxyl and methyl groups so that the yield produced in ethyl acetate solvent is less. In the n-hexane solvent, the yield value is low because the non-polar bioactive compounds such as terpenoids, waxes, color pigments, sterols, and alkaloids in the stem bark of $A$. occidentale are few. Pratiwi et al. (2016) stated that n-hexane and ethyl acetate solvents could attract fewer secondary metabolites in the sample than the sympathetic weight of $1.650 \mathrm{~g}$ of $\mathrm{n}$-hexane solvent has a yield weight of $0.32 \%$ and ethyl acetate of $5.94 \%$, while the ethanol solvent has a weight. The highest yield was $17.58 \%$. This is supported by Priandi et al. (2019) methanol solvent dissolves many polar and non-polar compounds in the extract of A. occidentale stem bark with an extract yield of $23.51 \%$.

\section{Antioxidant activity}

Antioxidant testing of $A$. occidentale stem bark samples was carried out with DPPH solution. $\mathrm{DPPH}$ is a stable free radical with a high enough sensitivity to samples with low concentrations (Maesaroh et al., 2018; Romadanu et al., 2014). The principle of measuring the antioxidant activity by DPPH is based on the reduction-oxidation reaction. The color change from yellow to dark purple in the DPPH solution occurs due to a reaction between DPPH and the bioactive components of the sample, one of which is an antioxidant compound (Nurfadillah et al., 2016). Measurement of antioxidant activity using UV-Vis spectrophotometer data obtained in the form of absorbance. The antioxidant properties of $A$. occidentale stem bark extract in n-hexane, ethyl acetate, and methanol solvents based on the $\mathrm{IC}_{50}$ value can be seen in Table 2 .

Antioxidant activity with powerful properties, namely methanol extract with $\mathrm{IC}_{50}$ value of 47.13 ppm, the antioxidant activity of ethyl acetate extract was weaker than methanol extract and more potent than $\mathrm{n}$-hexane extract with $\mathrm{IC}_{50}$ value of 163.92 ppm. The n-hexane extract had an $\mathrm{IC}_{50}$ value of $501.72 \mathrm{ppm}$. A low $\mathrm{IC}_{50}$ value indicates high free radical inhibition, meaning that the sample's ability to reduce DPPH radicals is getting bigger (Notariza \& Krisnamurti, 2019; Nurfadillah et a.l, 2016; Maesaroh et al., 2018; Romadanu et al., 2014). The following is a graph of the intensity of the antioxidant power of the sample:

Table 2. Antioxidant activity from $A$. occidantela extract

\begin{tabular}{cc}
\hline Extract & $\mathrm{IC}_{50}$ \\
\hline$n$-hexane & 501.72 \\
Ethyl Acetate & 163.92 \\
Methanol & 47.13 \\
Vitamin C & 1.81 \\
\hline
\end{tabular}

Antioxidant activity is related to secondary metabolites of flavonoids, alkaloids, tannins, steroids, terpenoids, saponins which can act as antioxidants. The difference in $\mathrm{IC}_{50}$ values between the three solvents is because each solvent attracts chemical compounds with different polarities. Methanol solvent has the lowest $\mathrm{IC}_{50}$ value. It is thought that polar chemical compounds act as high amounts of antioxidants such as flavonoids, tannins, and polyphenols. Arifin \& Ibrahim (2018) stated that secondary metabolite compounds of the flavonoid group have free radical scavenging activity because of the ability to pass through their free hydroxyl groups and depend on the configuration of the hydroxyl group in the core structure. Malangngi et al. (2012) explained that tannins have antioxidant activity because they are composed of polyphenol compounds as free radical scavengers.

\section{Characterization of the most active extracts using $L C-M S / M S$}

The compounds contained in methanol extract were identified using LC-MS/MS. 20 peaks were identified at a retention time of $0.80 ; 1.30 ; 2.38$; $2.99 ; 3.24 ; 3.83 ; 4.53 ; 5.04 ; 6.36 ; 7.34 ; 7.85 ; 9.30$; $10.48 ; 11.01 ; 11.48 ; 11.81 ; 12.30 ; 12.73 ; 14.27$ and 14.84. Only 2 peaks were detected (1.30 and 3.24); the other 18 peaks were unknown. Two compounds at the retention times of 1.30 and 3.24 were epigallocatechin and epigallocatechin gallate. The epigallocatechin and epigallocatechin gallate compounds are included in the flavonoid group with activity as antioxidants and anti-inflammatory (Leslie \& Gunawan, 2019). Flavonoids can donate hydrogen atoms to free radicals through a neutralization reaction to reduce free radicals 
(Handayani et al., 2014). The epigallocatechin compound has been isolated from the same family as A. occidentale, namely in Spondias mombin, the epigallocatechin and epigallocatechin gallate compounds have better antioxidant activity. They are higher in vitamins $\mathrm{C}$ and $\mathrm{E}$ (Nailufa \& Najih, 2020).

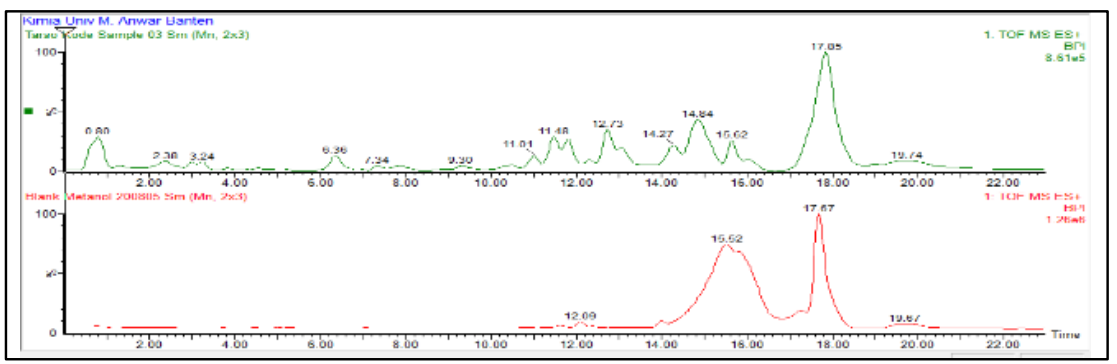

A

B

Figure 1. Chromatogram of the methanol extract of the stem bark of $A$. occidentale (A) and bank (B)<smiles>Oc1cc(O)c2c(c1)O[C@H](c1cc(O)c(O)c(O)c1)[C@H](O)C2</smiles><smiles>O=C(O)c1cc(O)c(O)c(O)c1C1Cc2c(O)cc(O)cc2OC1c1cc(O)c(O)c(O)c1</smiles>

Figure 2. The chemical structure of epigallocatechin and epigallocarechin gallate

Narmada et al. (2020) stated that epigallocatechin and epigallocatechin gallate compounds are found in tea plants (Camellia sinensis) and have extreme antioxidant activity with an $\mathrm{IC}_{50}$ value $36.71 \mu \mathrm{g} / \mathrm{mL}$. Sang et al. (2002) explained that epigallocatechin and epigallocatechin gallate compounds donate their hydrogen atoms to DPPH free radicals to reduce free radicals.

\section{Conclusion}

The methanol extract of $A$. occidentale stem bark has extreme antioxidant activity with an $\mathrm{IC}_{50}$ value of $47.13 \mathrm{ppm}$. LCMS/MS analysis of methanol extract contains epigallocatechin and epigallocatechin gallate compounds.

\section{Acknowledgment}

The author would like to thank the Forensic Laboratory of the MABES POLRI for assisting in the LCMS/MS analysis. STAK Cilegon has assisted in the analysis of antioxidants.

\section{References}

Arief, H., \& Widodo, M. A. (2016). Peranan stres oksidatif pada proses penyembuhan luka. Jurnal Ilmiah Kedokteran Wijaja Kusuma, 5(2), 22-29.

Anwar, Y. A. S. (2017). Antioxidant activity of cashew apple dreg extract and their effect in traditional processing of coconut oil.
ALCHEMY Jurnal Penelitian Kimia, 13(1), 1728.

Arifin, B., \& Ibrahim, S. (2018). Struktur, bioaktivitas dan antioksidan flavonoid. Jurnal Zarah, 6(1), 21-29.

Arnanda, Q. P., \& Nuwarda, R. F. (2019). Review Artikel: Penggunaan radiofarmaka teknesium$99 \mathrm{~m}$ dari senyawa glutation dan senyawa flavonoid sebagai deteksi dini radikal bebas pemicu kanker. Farmaka, 17(2), 236-243.

Carolus, F. P., Fatimawali., \& Wewengkang, D. S. (2014). Uji efektifitas ekstrak kulit batang jambu mete (Anacardium occidentale L.) terhadap penurunan kadar glukosa darah pada tikus putih jantan galur wistar (Rattus norvegicus) yang diinduksi aloksan. Pharmacon: Jurnal Ilmiah Farmasi, 3(3), 204-210.

Dahlia, A. A., \& Hasnawati. (2014). Isolasi dan identifikasi golongan kimia aktif antioksidan ekstrak etanol daun jambu mete (Anacardium occidentale L.). Jurnal Fitofarmaka Indonesia, 1(1), 24-30.

Damayanti, A., \& Fitriana, E. A. (2012). Pemungutan minyak atrsiri mawar (Rose Oil) dengan metode maserasi. Jurnal Bahan Alam Terbarukan, 1(2), 1-8. 
Handayani, V., Ahmad, A. R., \& Sudir, M. (2014). Uji aktivitas antioksidan ekstrak metanol bunga dan daun patikala (Etlingera elatior (Jack) R. M. $\mathrm{Sm})$ menggunakan metode DPPH. Pharmaceutical Science and Research (PSR), 1(2), 86-93.

Hasnaeni., Usman, S., \& Wisdawati. (2019). Pengaruh metode ekstraksi terhadap rendemen dan kadar fenolik ekstrak tanaman kayu betabeta (Lunasia amara Blanco). Jurnal Farmasi Galenika (Galenika Journal of Pharmacy), 5(2), 175-182.

Khaira, K. (2010). Menangkal radikal bebas dengan antioksidan. Jurnal Saintek, 2(2), 183-187.

Kusumowati, I. T. D., Melannisa, R., \& Ratri, K. (2011). Korelasi kandungan fenolik dan aktivitas antioksidan daun jambu mete. Biomedika, 3(2), 25-30.

Leslie, P. J., \& Gunawan, S. (2019). Uji fitokimia an perbandingan efek antioksidan pada daun teh hijau, teh hitam, dan teh putih (Camellia sinensis) dengan metode DPPH (2,2-difenil-1pikrilhidrazil). Tarumanagara Medical Journal, 1(2), 383-388.

Maesaroh, K., Kurnia, D., \& Anshori, J. A. (2018). Perbandingan metode uji aktivitas antioksidan DPPH, FRAP dan FIC terhadap asam askorbat, asam galat dan kuersetin. Chimica et Natura Acta, 6(2), 93-100.

Malangngi, L. P., Sangi, M. S., \& Paendong, J. J. E. (2012). Penentuan kandungan tanin dan uji aktivitas antioksidan ekstrak biji buah alpukat (Persea americana Mill.). Jurnal MIPA UNSRAT, 1(1), 5-10.

Molyneux, P. (2004). The use of the stable free radical diphenylpicrylhydrazil (DPPH) for estimating antioxidant activity. Songklanakarin Journal of Science and Technology, 26(2), 212219.

Nailufa, Y., \& Najih, Y. A. (2020). Formulasi krim epigallocatechin sebagai anti-aging. Journal of Pharmacy and Science, 5(2), 81-85.

Narmada, I. B., Sarasati, A., Wicaksono, S., Rezkita, F., Wibawa, K. G. P., Hayaza, S., \& Nugraha, A. P. (2020). Phytochemical screening, antioxidant activity, fuctional groups and chemical element characterization anaysis of ()-epigallocatechin-3- gallate (EGCG) in east javanese green tea methanolic extract: An experimental in vitro study. Systemic Reviews in Pharmacy, 11(5), 511-519.

Notariza, K. R., \& Krisnamurti, D. G. B. (2019). Perbandingan aktivitas antioksidan campuran ekstrak etanol $A$. indica dan $C$. asiatica terhadap ekstrak etanol $A$. indica. e-Journal Kedokteran Indonesia, 5(2), 98-104.

Nurfadillah., Chadijah, S., \& Rustiah, W. (2016). Analisis antioksidan ekstrak etil asetat dari kulit buah rambutan (Nephelium lappaceum) dengan menggunakan metode DPPH $(1,1$ difenil-2pikrilhidrazil). Al-Kimia, 4(1), 78-86.
Pratiwi, L., Fudholi, A., Martien, R., \& Pramono, S. (2016). Ekstrak etanol, ekstrak etil asetat, fraksi etil asetat dan fraksi $n$-heksan kulit manggis (Garcinia mangostana L.) sebagai sumber zat bioaktif penangkal radikal bebas. Journal of Pharmaceutical Science and Clinical Research, 1(1), 71-82.

Priandi, F., Yusro, F., Diba, F., Mariani, Y., \& Nurhaida. (2019). Uji efektifitas antibakteri ekstrak kulit batang jambu monyet (Bellucia pentamera Naudin) terhadap pertumbuhan bakteri Escherichia coli dan Salmonella typhi. Jurnal Tengkawang, 9(1), 27-37.

Romadanu., Rachmawati, S. H., \& Lestari, S. D. (2014). Pengujian aktivitas antioksidan ekstrak bunga lotus (Nelumbo nucifera). Jurnal Fishtech, 3(1), 1-7.

Rudiana, T., Suryani, N., Indriatmoko, D. D., Yusransyah, Amelia, A., Noviany, \& Hadi, S. (2019). Characterization of oxidative fraction of plant stem Bouea macrophylla Griff. Journal of Physics: Conference Series, 1314, 1-8.

Sang, S., Cheng, X., Stark, R. E., Rosen, R. T., Yang, C. S., \& Ho, C. T., (2002). Chemical studies on antioxidant mechanism of tea catechin: Analysis of radical reaction product of catechin and epicatechin with 2,2-diphenyl-1picrylhydrazil. Bioorganic and Medicinal Chemistry, 10(7), 2233-2237.

Sinaga, F. A. (2016). Stress oksidatif dan status antioksidan pada aktivitas fisik maksimal. Jurnal Generasi Kampus, 9(2), 176-189.

Sogandi, G., Darma, W. S. T., \& Jannah, R. (2019). Potensi senyawa antibakteri dari ekstrak akar manis (Glycyrrhiza glabra L.) terhadap Bacillus cereus. Jurnal Kimia Sains dan Aplikasi, 22(4), 105-111.

Soleha, F. (2018). Pengaruh metode ekstraksi maserasi terhadap aktivitas antibakteri daun sirih merah (Piper crocatum Ruiz \& Pav) pada bakteri Staphylococcus aureus menggunakan metode sumur difusi. Jurnal Analis Farmasi, 3(1), 62-70.

Tangkuman, A. R. I., Fatimawali., \& Citraningtyas, G. (2017). Uji aktivitas antibakteri ekstrak etanol kulit batang jambu mete (Anacardium occidentale L.) dalam menghambat pertumbuhan bakteri dari air liur penderita sariawan. Pharmacon: Jurnal Ilmiah Farmasi, 6(2), 7-13.

World Health Organization (WHO). (2019). Monitoring health for the sustainable development goals. Retrieved November 15, 2010,

from Available:https://apps.who.int/iris/bitstrea m/handle/10665/311696/WHO-DAD2019.1-eng.pdf.

Yati, S. J., Sumpono., \& Candra, I. N. (2018). Potensi aktivitas antioksidan metabolit sekunder dari bakteri endofit pada daun 
Mongifera oleifera L. ALOTROP, Jurnal

Pendidikan dan Ilmu Kimia, 2(1), 82-87. 